\title{
Phosphorus efficiency modulates phenol metabolism in wheat genotypes
}

\author{
Sofía Pontigo ${ }^{1,2}$, Marlys Ulloa ${ }^{1,2}$, Karina Godoy ${ }^{2}$, Nina Nikolic ${ }^{3}$, Miroslav Nikolic ${ }^{3}$, María \\ de la Luz Mora ${ }^{2,4}$, Paula Cartes ${ }^{2,4 *}$
}

${ }^{1}$ Programa de Doctorado en Ciencias de Recursos Naturales, Universidad de La Frontera, Avenida Francisco Salazar 01145, P.O. Box 54-D, Temuco, Chile. ${ }^{2}$ Center of Plant-Soil Interaction and Natural Resources Biotechnology, Scientific and Technological Bioresource Nucleus (BIOREN-UFRO), Universidad de La Frontera, Avenida Francisco Salazar 01145, P.O. Box 54-D, Temuco, Chile. ${ }^{3}$ Plant Nutrition Research Group, Institute for Multidisciplinary Research, University of Belgrade, P.O. Box 33, Belgrade, Serbia. ${ }^{4}$ Departamento de Ciencias Químicas y Recursos Naturales, Facultad de Ingeniería y Ciencias, Universidad de La Frontera, Avenida Francisco Salazar 01145, P.O. Box 54-D, Temuco, Chile.*Correspondingauthor: paula.cartes@ufrontera.cl

\begin{abstract}
The effect of phosphorus (P) supply on $\mathrm{P}$ uptake, plant growth, and phenols production with either antioxidant or structural function was investigated in wheat. Ten wheat cultivars were grown hydroponically at $0,0.01$, 0.1, $0.4 \mathrm{mM}$ P. After harvest, P concentration, plant growth, lipid peroxidation and total phenols concentration were determined. Chloroplasts hydrogen peroxide $\left(\mathrm{H}_{2} \mathrm{O}_{2}\right)$ production and lignin distribution were also analyzed. According to the nutritional requirements of wheat, the application of both $0.1 \mathrm{mM} \mathrm{P}$ and $0.4 \mathrm{mM}$ P provided sufficient $\mathrm{P}$ levels. However, $\mathrm{P}$ concentration in wheat cultivars treated with either 0 or $0.01 \mathrm{mM} P$ reached a $\mathrm{P}$ deficient state. Almost all cultivars reduced shoot biomass under $\mathrm{P}$ shortage, which in turn led to increase root growth and root/shoot ratio. Consequently, genotypes with contrasting P efficiency were defined. The oxidative damage, chloroplast $\mathrm{H}_{2} \mathrm{O}_{2}$ production, total phenols and lignin accumulation augmented in wheat cultivars as $\mathrm{P}$ supply decreased. Moreover, P-inefficient genotypes accumulated more total phenols in their tissues than Pefficient genotypes under P-deficient conditions. In fact, a clear relationship between P efficiency and phenol metabolism was found. Additionally, based on our results, we ranked wheat cultivars according to their susceptibly to P deficiency.
\end{abstract}

Keywords: Phosphorus, oxidative stress, phenols, lignin, wheat 


\section{Introduction}

Phosphorus (P) is one of the major macronutrients required for plant growth and metabolism. It is a structural constituent of nucleic acids, phospholipids and ATP, and performs essential roles in energy transfer reactions, signal transduction, and the activation of proteins (Vance et al., 2003; Shen et al., 2011). In plants, $\mathrm{P}$ is taken up by the roots as inorganic phosphate $\left(\mathrm{Pi} ; \mathrm{H}_{2} \mathrm{PO}_{4}^{-}\right.$and $\mathrm{HPO}_{4}^{2-}$ ). Phosphorus availability is restricted; in the majority of soils it forms insoluble complexes with cations such as iron $(\mathrm{Fe})$, aluminium ( $\mathrm{Al}$ ) or calcium $(\mathrm{Ca})$, as well as it is rapidly adsorbed by mineral surfaces and organic matter in a pH-dependent process (Vance et al., 2003; Redel et al., 2016; Velásquez et al., 2016).

Phosphorus efficiency (i.e. efficiency of acquisition and internal utilization of $\mathrm{P}$ ) is a composite constitutive trait of plant genotypes which enables growth maintenance along the gradient of $\mathrm{P}$ availability (Gourley et al., 1993). Phosphorus efficiency is achieved through a range of plant adaptive strategies generally associated with both morphological and biochemical traits aimed to enhance the acquisition of $\mathrm{P}$ from soil (Vance et al., 2003; Shen et al., 2011; Balemi and Negisho 2012). Common responses of $\mathrm{P}$ efficient genotypes to low $\mathrm{P}$ availability include: (i) modifications to root architecture (e.g., increased root growth, lateral roots and root-hair density, formation of cluster roots; (ii) changes in carbon (C) metabolism and thylakoid membrane structure; (iii) formation of mycorrhizal symbiosis; (iv) enhanced expression of genes involved in low-P adaptation; and (v) synthesis of acid phosphatase enzymes, proton release and exudation of organic compounds (Neumann and Römheld 2001; Vance et al., 2003; Shen et al., 2011; Niu et al., 2012).
Biosynthesis and accumulation of phenolic compounds is another common, but less studied strategy of plants to overcome various mineral stresses including P deficiency (Plaxton and Carswell 1999; Dakora and Phillips 2002; Malusà et al., 2006). These compounds are plant secondary metabolites that have significant physiological and structural roles acting as either signaling molecules, regulators of phytohormone transport or agents in plant defense (Dixon et al., 2002). Phenolic compounds are frequently reported to be one of the main components of root exudates, which can foster the uptake of low soluble or scarcely available mineral nutrients (Dakora and Phillips 2002). In the case of $\mathrm{P}$, exuded phenolics can act as chelators and/or reductants augmenting the release of fixed $\mathrm{P}$ (Dakora and Phillips 2002). High phenolic exudation, especially of flavonoids, and changes in the enzyme activities of the phenylpropanoid pathway have also been found in roots of plants grown under P-deficiency (Plaxton and Carswell 1999; Malusà et al., 2006). Moreover, phenolic exudation into the rhizosphere could indirectly improve P uptake by stimulation of microbial growth (Tsai and Phillips 1991) and prevention of the microbial degradation of some organic compounds (e.g., phosphatases and organic acids) released by roots of nutrient deficient plants (Neumann and Römheld 2001). So far, most of the studies have been devoted to investigate the role of phenolicsmediated alleviation of P deficiency in terms of root exudates. However, scarce attention has been paid to the antioxidant ability and/or structural functions that these compounds could provide to plant grown under $\mathrm{P}$ shortage. Some studies have reported that P-starved plants increased the accumulation of anthocyanins to cope with photo-oxidative stress (Vance et al., 2003; Hernández and Munné-Bosch 2015). On the other 
hand, Eppendorfer and Eggum (1994) showed that $\mathrm{P}$ deficiency led to increase in lignin content of potato tubers, but they did not give a possible explanation to this observation.

Phenolic compounds have also been associated with potential human health benefits derived from consuming of fruits, grains or edible plant parts. This fact could be particularly relevant for massively consumed species such as wheat (Triticum aestivum $\mathrm{L}$ ), which is one of a staple crop for human nutrition worldwide.

Wheat is also the most commonly cereal cultivated in Chile (ODEPA, 2016). Nevertheless, wheat yields commonly can be reduced since it is frequently cultivated on P-deficient acid soils. In Chile, currently there are about 70 certified wheat cultivars (SAG, 2017), which differ widely in yield depending on their ability to tolerate $\mathrm{P}$ deficiency. The production of phenolic compounds as a protection mechanism against $P$ deficiency stress could be an important strategy of $P$ efficient cultivars. The aim of this study was therefore to assess the effect of P supply on P uptake, plant growth, and phenols production with either antioxidant or structural function in different wheat cultivars grown under hydroponic conditions.

\section{Materials and Methods}

\subsection{Plant material and growth conditions}

Wheat (Triticum aestivum L.) seeds of ten cultivars (BTP-314, Púrpura, Maxi, Ilustre Impulso, Bakán, Fritz, Don Crac, Dollinco, Innovo) were sterilized in 2\% (v/v) sodium hypochlorite for $10 \mathrm{~min}$ and germinated on wet filter paper in the plastic plates. After 12 $\mathrm{d}$ of germination, seedlings were transferred into 3-L plastic pots ( 28 plants per pot) filled with a continuously aerated basal nutrient solution proposed by Taylor and Foy (1985). After a conditioning period of 7 days, four P levels $(0,0.01,0.1$ or $0.4 \mathrm{mM} \mathrm{P}$; supplied as $\mathrm{K}_{2} \mathrm{HPO}_{4}$ ) were applied in a completely randomized factorial design with three replicates per treatment. Control plants corresponded to those supplied with $0.1 \mathrm{mM}$ according to nutritional requirement of wheat (Jones et al., 1991). During the experiment, the nutrient solution was replaced every $7 \mathrm{~d}$, and the $\mathrm{pH}$ was adjusted to 6.0 with diluted $\mathrm{HCl}$ or $\mathrm{NaOH}$ and checked daily. Plants were grown under controlled conditions at $25 / 20{ }^{\circ} \mathrm{C}$ day/night temperature, a $16 / 8$ $\mathrm{h}$ (light/dark) photoperiod, $350 \mu \mathrm{mol} \mathrm{m} \mathrm{m}^{-2} \mathrm{~s}^{-1}$ photosynthetic photon flux density and $70-80 \%$ relative humidity. Plants were harvested $21 \mathrm{~d}$ after the exposure to different $\mathrm{P}$ treatments. Shoot and root material were divided to subsamples; for biochemical analyses the fresh material was stored at $-20{ }^{\circ} \mathrm{C}$ or $-80{ }^{\circ} \mathrm{C}$ and for chemical analysis it was oven dried.

\subsection{Plant growth and $P$ mineral concentration}

Subsamples of fresh material were oven dried at $65^{\circ} \mathrm{C}$ for $48 \mathrm{~h}$ to determine dry weight (DW) and the concentration of $\mathrm{P}$ in plant tissues. For $\mathrm{P}$ chemical analysis, $0.1 \mathrm{~g}$ of dried pulverized material were ashed at $500{ }^{\circ} \mathrm{C}$ for $8 \mathrm{~h}$, and treated with $2 \mathrm{M}$ hydrochloric acid as described by Sadzawka et al. (2007); P concentrations were spectrophotometrically determined at 466 $\mathrm{nm}$ by the molybdo-vanadate method.

\subsection{Lipid peroxidation measurements}

Lipid peroxidation was assessed in fresh material by monitoring the thiobarbituric acid reactive substances (TBARS) following the modified method of Du and Bramlage (1992). The absorbance was measured at 532,600 and $440 \mathrm{~nm}$ to correct the interferences produced by TBARS-sugar complexes. 


\subsection{Detection of $\mathrm{H}_{2} \mathrm{O}_{2}$ production by flow cytometry}

Suspensions of intact chloroplasts were isolated from shoot samples using Sigma Chloroplast Isolation Kit (Sigma-Aldrich, St. Louis MO, USA). The chloroplasts were centrifuged at 2,500 $\times$ g for $5 \mathrm{~min}$ at $4{ }^{\circ} \mathrm{C}$ and subsequently incubated at $37{ }^{\circ} \mathrm{C}$ with the fluorescent probe $2^{\prime}, 7^{\prime}$-dichlorodihydrofluorescein diacetate $\left(\mathrm{H}_{2} \mathrm{DCFDA}\right)$ to detect intracellular $\mathrm{H}_{2} \mathrm{O}_{2}$ according to the method described by Maxwell et al. (1999) with some modifications. A positive control (intact chloroplast plus $100 \mu \mathrm{M} \mathrm{H}_{2} \mathrm{O}_{2}$ ) and negative control (suspension of intact chloroplasts without $\mathrm{H}_{2} \mathrm{O}_{2}$ ) were considered. The samples were analyzed by Flow Cytometer FACS Canto II-Becton Dickinson-USA. The data were processed using the FACSDivaTM software v 6.0.

\subsection{Determination of total phenol concentration}

Total soluble phenols were determined spectrophotometrically at $765 \mathrm{~nm}$ using Folin-Ciocalteu reagent according to the method described by Slinkard and Singleton (1977) with slight modifications. The concentrations total phenols were calculated using chlorogenic acid as a standard.

\subsection{Lignin visualization assay}

Lignin distribution in roots, previously stained with $0.1 \%$ Safranin O, was examined using a Laser Scanning Confocal Microscopy (CLSM; FV1000 Olympus-Japan). Auto-fluorescence was recorded at excitation/emission of $488 / 530 \mathrm{~nm}$, whereas a 543 $\mathrm{nm}$ excitation laser and an emission of $590 \mathrm{~nm}$ were used to detect the Safranine staining as described by Sant'Anna et al. (2013). The images were processed using the FV10-ASW v0.200c Software; OlympusJapan. The detection of safranine fluorescence was expressed as Relative Fluorescence Unit (RFU). Accordingly, different regions of interest in each image were selected and the RFU averages calculated.

\subsection{Data analysis}

The effect of $\mathrm{P}$ supply on different parameters in 10 wheat genotypes was tested using the analysis of variance (ANOVA) model, after normality and homoscedasticity tests. Significance of the differences among means was analyzed by the least significant difference (LSD) test at the 0.05 significance level. For analyzing the strength of linear correlation among the measured response variables in wheat, data was pooled from all the 4 levels of P supply in all the genotypes tested; significance of Pearson coefficients was assessed by t-test. The effect of P efficiency in modulating the concentrations of total phenols along the $\mathrm{P}$ supply gradient was analyzed by ANCOVA in GRM module (STATISTICA 6 software, StatSoft Inc., Tulsa, USA).

\section{Results}

\subsection{Phosphorus concentration and plant growth}

Phosphorus concentration gradually augmented in both shoots and roots of all wheat cultivars by increasing $\mathrm{P}$ doses (Figure 1A-B). Under an adequate $\mathrm{P}$ dose (0.1 $\mathrm{mM}$, which corresponded to the control treatment), the cultivars reached an average $P$ concentration of $4.1 \pm$ $0.1 \mathrm{~g} \mathrm{~kg}^{-1} \mathrm{DW}$ in shoots (Figure 1A), with exception of cv. Impulso that achieved the highest shoot $\mathrm{P}$ concentration $\left(5.6 \pm 0.2 \mathrm{~g} \mathrm{~kg}^{-1} \mathrm{DW}\right)$. In addition, $\mathrm{P}$ concentration ranged between $2.2 \pm 0.2 \mathrm{~g} \mathrm{~kg}^{-1} \mathrm{DW}$ and $5.2 \pm 0.2 \mathrm{~g}$ $\mathrm{kg}^{-1} \mathrm{DW}$ in roots of plants receiving $0.1 \mathrm{mM} \mathrm{P}$ (Figure 1B). The application of the highest $\mathrm{P}$ dose $(0.4 \mathrm{mM})$ significantly increased $\mathrm{P}$ concentration in tissues of almost all cultivars, reaching $P$ concentrations up to $7.8 \pm$ $0.2 \mathrm{~g} \mathrm{~kg}^{-1} \mathrm{DW}$ in shoots (e.g. cv. Impulso) and about 6.7 
$\pm 0.1 \mathrm{~g} \mathrm{~kg}^{-1} \mathrm{DW}$ in roots (e.g. cv. Dollinco) (Figure 1). In general, all wheat cultivars preferentially accumulated $\mathrm{P}$ in the shoots irrespectively of the added $\mathrm{P}$ amount. However, a lower $\mathrm{P}$ translocation from roots to shoots was observed when plants were grown without $\mathrm{P}$ or with $0.01 \mathrm{mM}$ P. Accordingly, cultivars grown without $P$ reached an average $P$ concentration of $1.3 \pm 0.1 \mathrm{~g} \mathrm{~kg}^{-1}$ DW and $1.1 \pm 0.1 \mathrm{~g} \mathrm{~kg}^{-1} \mathrm{DW}$ in shoots and roots, respectively (Figure 1). Low P concentrations were also detected in the tissues of cultivars supplied with 0.01 $\mathrm{mM}$ P. In relation to the control plants, the application of $0.01 \mathrm{mM}$ P decreased the shoot $\mathrm{P}$ concentration from $4.2 \pm 0.2 \mathrm{~g} \mathrm{~kg}^{-1} \mathrm{DW}$ to $1.2 \pm 0.0 \mathrm{~g} \mathrm{~kg}^{-1} \mathrm{DW}$ and from $4.1 \pm 0.1 \mathrm{~g} \mathrm{~kg}^{-1}$ DW to $1.3 \pm 0.1 \mathrm{~g} \mathrm{~kg}^{-1}$ DW in BTP-314 and Púrpura, respectively (Figure 1A). Nevertheless, cultivars such as Ilustre, Impulso and Fritz treated with $0.01 \mathrm{mM} P$ achieved P concentrations above $2.0 \mathrm{~g} \mathrm{~kg}^{-1}$ $\mathrm{DW}$ in shoots. Furthermore, a significant reduction of $\mathrm{P}$ concentration was detected in roots of BTP-314 (81\%) and Púrpura (77\%) treated with $0.01 \mathrm{mM} \mathrm{P}$ compared to those supplied with $0.1 \mathrm{mM}$ (Figure 1B).
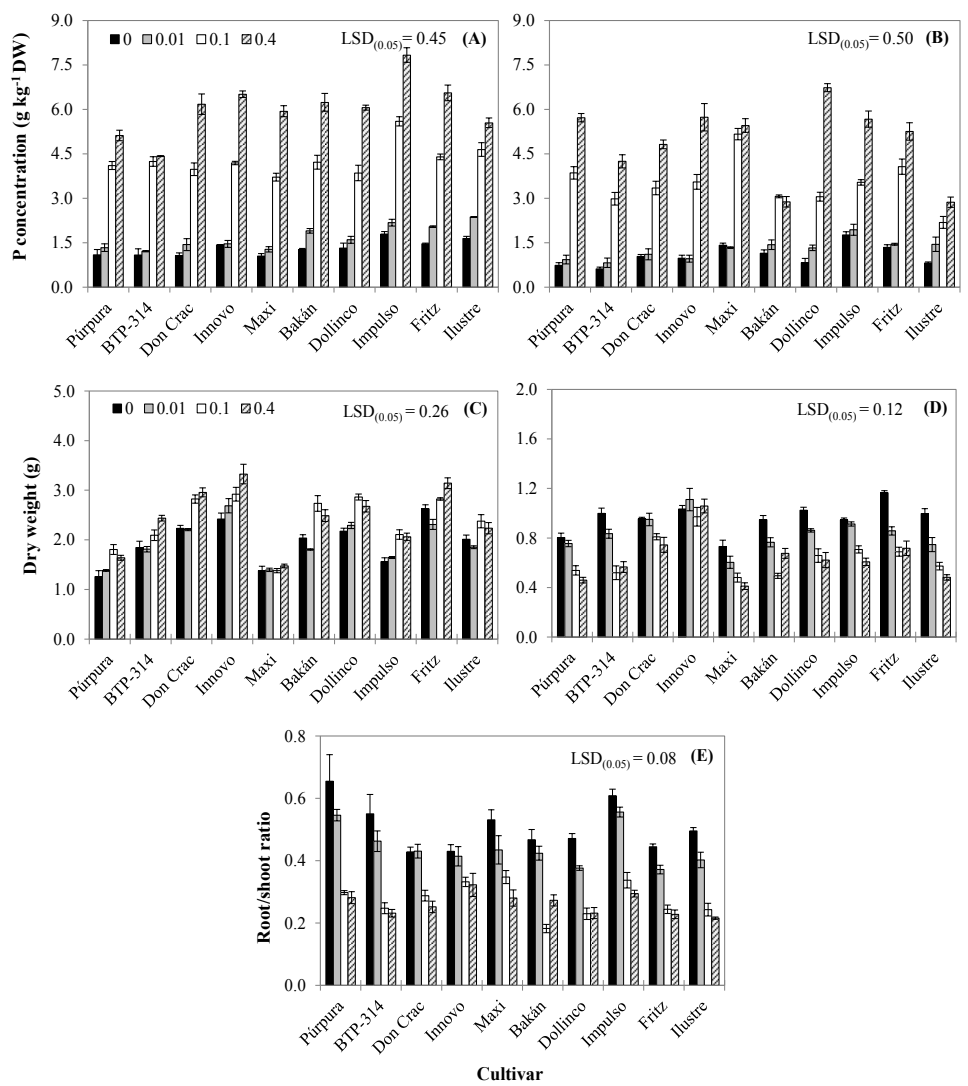

Figure 1. Phosphorus concentration and dry matter production in shoots (A-C) and roots (B-D), and root/shoot ratio $(\mathrm{E})$ of different wheat cultivars hydroponically grown at $0,0.01,0.1,0.4 \mathrm{mM}$ P. Data are means of three replicates \pm standard error. Differences among response means in each cultivar along $\mathrm{P}$ supply gradient were identified using the least significant difference (LSD) test at the 0.05 significance level. 
Regarding plant growth, shoot dry weight (DW) of the wheat cultivars supplied with $0.1 \mathrm{mM} P$ varied from $1.4 \pm 0.1 \mathrm{~g} \mathrm{pot}^{-1}$ to $2.9 \pm 0.1 \mathrm{~g} \mathrm{pot}^{-1}$, with an average of $2.4 \pm 0.1 \mathrm{~g} \mathrm{pot}^{-1}$ for all examined cultivars (Figure 1C). Additionally, the roots of wheat cultivars subjected to an adequate $\mathrm{P}$ supply produced an average dry biomass of $0.6 \pm 0.1 \mathrm{~g} \mathrm{pot}^{-1}$ (Figure 1D). The cultivars supplied with $0.4 \mathrm{mM} P$ did not show significant differences in DW compared with those subjected to $0.1 \mathrm{mM}$ P; the exception being in the cvs. BTP314, Fritz and Innovo, that slightly increased shoot DW in $16 \%, 11 \%$ and $14 \%$ respectively (Figure 1C). In contrast, almost all cultivars diminished the shoot biomass under P limitation. With $0.01 \mathrm{mM} P$ application, highest decrease of shoot dry weight was found in Bakán (35\%) followed by Púrpura (23\%), Ilustre (22\%), Impulso (22\%), Don Crac (22\%) and Dollinco
$(20 \%)$, whereas no changes in the shoot yield were observed in Maxi (Figure 1C).

Different to shoot, low P levels triggered an increment of root growth in almost all cultivars, which reached an average root DW of $0.8 \pm 0.1 \mathrm{~g} \mathrm{~kg}^{-1}$ and $1.0 \pm 0.1 \mathrm{~g}$ $\mathrm{kg}^{-1}$ with the $0.01 \mathrm{mM} P$ and $0 \mathrm{mM} P$ treatments, respectively (Figure 1D). Excluding cv. Innovo, all the other wheat cultivars significantly increased the root growth under P limitation. For example, cv. BTP-314 increased root DW up to $61 \%$ at $0.01 \mathrm{mM} \mathrm{P}$ and by about $92 \%$ compared with the absence of $\mathrm{P}$ application. Moreover, the root/shoot ratio increased at least 1.5 -fold in cultivars grown at low P levels compared to those supplied with an optimal P dose (Figure 1E). Consequently, plant growth was positively correlated with $\mathrm{P}$ concentration in shoots $(r=0.421, P \leq 0.01)$, but negatively related in roots $(r=-0.529, P \leq 0.01)$, as shown in Table 1.

Table 1. Pearson's correlation among plant $\mathrm{P}$ concentration, plant growth, lipid peroxidation (TBARS) and total phenol concentration of wheat cultivars subjected to different $\mathrm{P}$ treatments.

\begin{tabular}{lllll}
\hline & $\mathrm{P}$ & Dry weight & TBARS & Total phenols \\
\hline & & & Shoot & \\
$\mathrm{P}$ & 1.00 & & & \\
Dry weight & $0.421^{* *}$ & 1.00 & & \\
TBARS & $-0.720^{* *}$ & $-0.325^{* *}$ & 1.00 & \\
Total phenols & $-0.252^{* *}$ & 0.077 & $0.219^{*}$ & 1.00 \\
& & & Root & \\
P & 1.00 & & & \\
Dry weight & $-0.529^{* *}$ & 1.00 & & \\
TBARS & $-0.456^{* *}$ & $0.316^{* *}$ & 1.00 & \\
Total phenols & $-0.499^{* *}$ & $0.227^{*}$ & $0.238^{* *}$ & 1.00 \\
\hline
\end{tabular}

Asterisks indicate significance as follows: ${ }^{*} P \leq 0.01,{ }^{* *} P \leq 0.05$. 
The relative decrease of $\mathrm{P}$ uptake (calculated from Figure 1) when the external $P$ supply was reduced from 0.1 $\mathrm{mM} P$ to $0.01 \mathrm{mM}$ P was used to evaluate P efficiency of the tested genotypes (Table 2). This parameter assesses the capacity of a cultivar to maintain both shoot $\mathrm{P}$ concentrations and growth under $\mathrm{P}$ deficient conditions. With the 10-fold decrease of P supply, the decrease of
$\mathrm{P}$ uptake was by about $16 \%$ stronger in relatively $\mathrm{P}$ inefficient cultivars (BTP-314 and Púrpura) then in relatively P efficient cultivars (Illustre and Fritz; Table 2). Contrary to P-efficient cultivars, the P-inefficient ones more prominently decrease shoot $\mathrm{P}$ concentrations under $\mathrm{P}$ deficiency, and overall maintain lower shoot $\mathrm{P}$ levels across the gradient of P supply (Figure 2).

Table 2. Phosphorus efficiency of the tested wheat cultivars evaluated by the relative decrease of $\mathrm{P}$ uptake when the external P supply is reduced from $0.1 \mathrm{mM}$ to $0.01 \mathrm{mM}$. Cultivars are arranged in decreasing P efficiency.

\begin{tabular}{lc}
\hline Wheat cultivar & Relative decrease of P uptake (\%) \\
\hline Ilustre & 55.07 \\
Fritz & 58.16 \\
Impulso & 62.64 \\
Dollinco & 63.22 \\
Bakán & 65.37 \\
Maxi & 65.91 \\
Innovo & 68.40 \\
Don Crac & 69.77 \\
BTP-314 & 72.28 \\
Púrpura & 72.98 \\
\hline
\end{tabular}

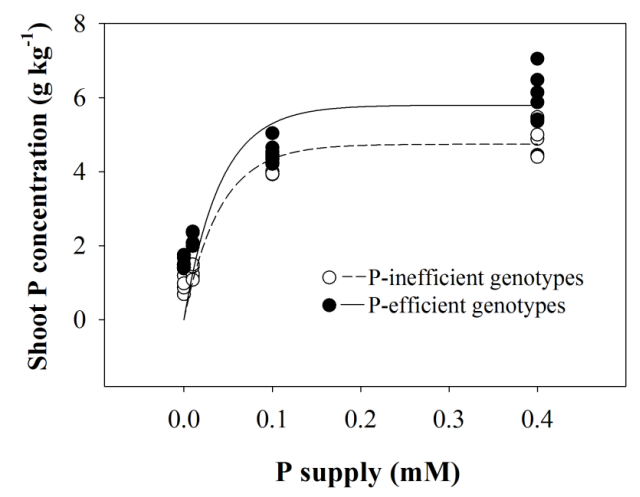

Figure 2. Differential responses of shoot $\mathrm{P}$ accumulation along the gradient of $\mathrm{P}$ supply in P-efficient (Fritz and Ilustre) and P-inefficient (BTP-314 and Purpura) wheat genotypes. Cultivars are selected based on the data shown in Figures 1 and 2. 


\subsection{Lipid peroxidation}

Compared to the control treatment, the level of lipid peroxidation was reduced in the shoots by at least $18 \%$ in Púrpura, Ilustre, Bakán and Don Crac at 0.4 mM P supplied (Figure 3A). Likewise, addition of the highest P level decreased TBARS accumulation in the roots of cvs. Maxi and Bakán by about $25 \%$ and $30 \%$, respectively (Figure 3B). Conversely, oxidative damage was significantly augmented in most of the cultivars as the dose of P supply decreased (Figure 3).

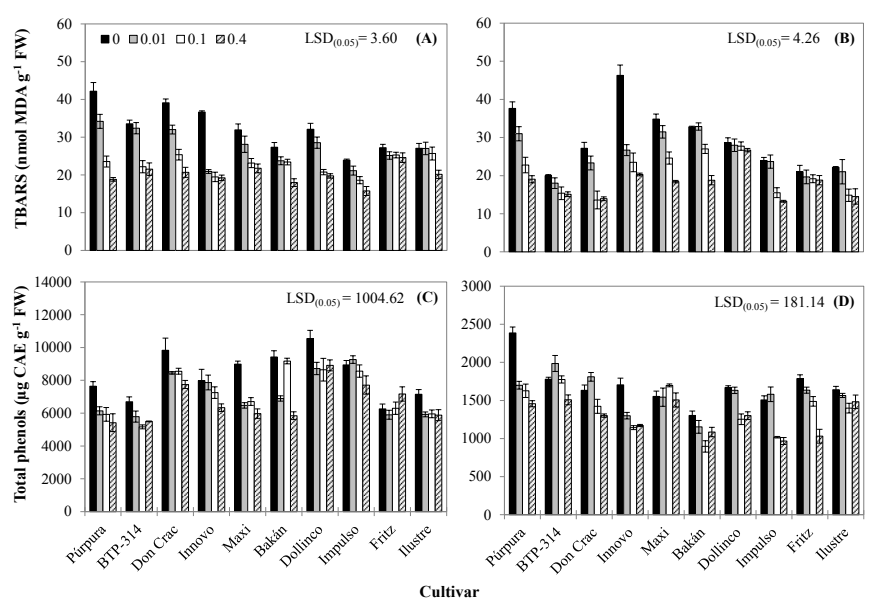

Figure 3. Lipid peroxidation and total phenol concentration in shoots (A-C) and roots (B-D) of different wheat cultivars hydroponically grown at $0,0.01,0.1,0.4 \mathrm{mM}$ P. Data are means of three replicates \pm standard error. Differences among response means in each cultivar along P supply gradient were identified using the least significant difference (LSD) test at the 0.05 significance level.

Relative to the control plants supplied with $0.1 \mathrm{mM}$ $\mathrm{P}$, the highest increment of the shoot lipid peroxidation was found in cvs. Innovo (88\%), Púrpura (79\%), Dollinco (55\%), Don Crac (54\%) and BTP-314 (51\%) grown without $\mathrm{P}$ supply (Figure $3 \mathrm{~A}$ ). In comparison with plants treated with $0.1 \mathrm{mM} \mathrm{P}$, shoot lipid peroxidation of BTP-314 and Púrpura supplied with $0.01 \mathrm{mM} P$ was increased up to 1.5 -fold. Similarly, TBARS accumulation considerably increased in roots of almost all cultivars grown under P shortage (Figure 3B)-Furthermore, a negative relationship between lipid peroxidation and $\mathrm{P}$ concentration in shoots $(r=$ $-0.720, P \leq 0.01)$ and roots $(r=-0.456, P \leq 0.01)$ of wheat cultivars grown under different $\mathrm{P}$ treatments was found (Table 1).

\subsection{Production of $\mathrm{H}_{2} \mathrm{O}_{2}$ in wheat chloroplasts}

Hydrogen peroxide production was tested in chloroplast of the wheat cultivars subjected to different $P$ treatments (Figure 4). Accordingly, the oxidation of $\mathrm{H}_{2}$ DCFDA probe rendered a progressive increase in 
chloroplast $\mathrm{H}_{2} \mathrm{O}_{2}$ generation in all tested wheat cultivars subjected to $\mathrm{P}$ deficiency. Compared to the control treatment, chloroplast $\mathrm{H}_{2} \mathrm{O}_{2}$ production in cv. Innovo supplied with $0.01 \mathrm{mM} P$ was 2.0 -fold higher, whereas it was less pronounced in cvs. Dollinco and Don Crac (1.8-fold and 1.5-fold, respectively; Figure 4). Likewise, the absence of P supply triggered a greater $\mathrm{H}_{2} \mathrm{O}_{2}$ generation in cv. Innovo (83\%) followed by Dollinco (78\%), Don Crac (58\%), Fritz (56\%), BTP-314 (45\%), Ilustre (27\%) and Purpura (21\%). Conversely, a slight reduction of the $\mathrm{H}_{2} \mathrm{O}_{2}$ production was detected in cvs. Impulso, Bakán, Maxi, Ilustre and Don Crac treated with the highest P dose compared to those subjected to $0.1 \mathrm{mM} P$ addition.

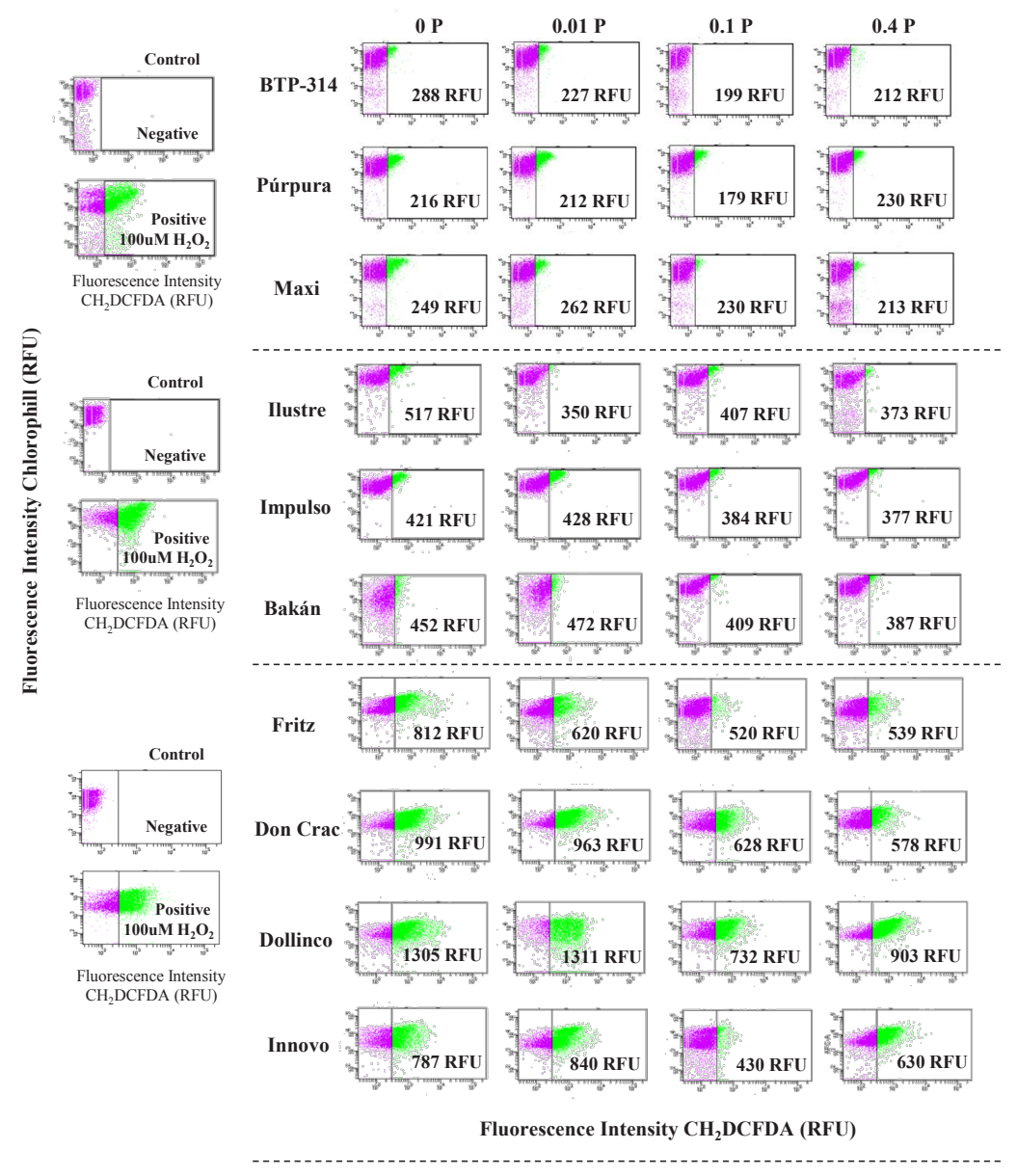

Figure 4. Dot plot showing the hydrogen peroxide $\left(\mathrm{H}_{2} \mathrm{O}_{2}\right)$ production in chloroplasts of wheat cultivars subjected to different $\mathrm{P}$ treatments. Dotted lines separate each set of samples assayed with their respective controls. For the positive control, $100 \mu \mathrm{M} \mathrm{H}_{2} \mathrm{O}_{2}$ was used. 
3.4. Tissue accumulation of phenols with antioxidant and structural functions

The concentration of total phenols was higher in the shoots than in the roots, with tendency to increase in the plant tissues under P deficiency (Figure 3C-D). Increments in the total phenols were more evident in the wheat cultivars cultivated without $\mathrm{P}$ than those supplied with $0.01 \mathrm{mM}$ P. Cultivars BTP-314, Púrpura and Maxi grown in the absence of $\mathrm{P}$ augmented the shoot total phenols concentration about 1.3-fold compared to plants supplied with an adequate $\mathrm{P}$ dose (Figure 3C).
Furthermore, overall P efficiency of a cultivar significantly modifies the accumulation of total phenols in wheat shoot (Figure 5A). The ANCOVA model indicates that the P-efficient and P-inefficient cultivars have the same intercept but different slopes (Table 3). At absolute $\mathrm{P}$ deprivation both types have about 6310 $\mu$ g CAE g ${ }^{-1}$. Whereas P-efficient genotypes maintain this level along the gradient of P supply (P supply regression coefficient not significant, Table 3), it appears that increased phenol accumulation is induced by $\mathrm{P}$ deficiency in shoots of P-inefficient genotypes (Figure 5A).

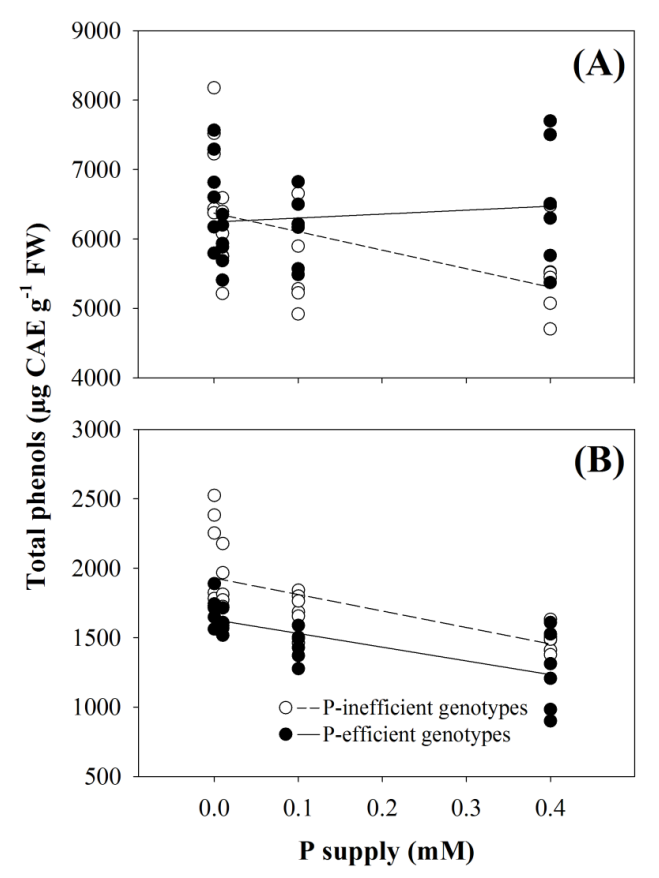

Figure 5. Phosphorus efficiency modulates phenol accumulation in shoots (A) and roots (B) of genotypes with contrasting P efficiency. Linear regression lines modeled by ANCOVA are shown. $\mathrm{A}: \mathrm{R}^{2} \mathrm{adj} .=0.13, \mathrm{~F}=3.36, \mathrm{p}=$ 0.027; B: $\mathrm{R}^{2}$ adj. $=0.55, \mathrm{~F}=29.4, \mathrm{p}=0.0000$. P efficient cultivars: Fritz and Ilustre; P-inefficient cultivars: BTP314 and Purpura. 
Table 3. Significant coefficients of regressing total phenols concentration on P supply in wheat genotypes of contrasting P efficiency.

\begin{tabular}{lcccc}
\hline Parameter & Coefficient \pm s .e. & p value & $-95 \%$ CL & $+95 \%$ CL \\
\hline & \multicolumn{2}{c}{ Shoot } & & \\
Intercept & $6310.6 \pm 137.5$ & 0.00000 & 6033.4 & 6587.8 \\
P efficiency x P supply & $-1616.6 \pm 666.9$ & 0.019 & -2960.8 & 272.4 \\
& \multicolumn{2}{c}{ Root } & & \\
Intercept & $1779.1 \pm 37.1$ & 0.00000 & 1704.5 & 1853.8 \\
P supply & $-1087.7 \pm 179.7$ & 0.00000 & -1449.7 & -725.7 \\
P efficiency & $137.0 \pm 29.1$ & 0.00025 & 78.3 & 195.6 \\
& & & & \\
\hline
\end{tabular}

s.e. - standard error of the estimated coefficient

$\mathrm{CL}$ - confidence limit of the estimate

P efficient genotypes: Ilustre and Fritz; P inefficient genotypes: BTP-314 and Purpura

The addition of $0.01 \mathrm{mM} P$ also enhanced the concentration of root phenols about 1.6-fold in cv. Impulso and by about 1.3-fold in cvs. Dollinco, Bakán and Don Crac (Figure 3D). Similarly, the root phenols concentration of cvs. Púrpura, Impulso, Innovo and Bakán grown without $\mathrm{P}$ was about 1.5-fold higher than of those supplied with $0.1 \mathrm{mM}$, whereas there was only a slight increase recorded in cvs. Ilustre, Fritz and Dollinco (Figure 3D). Indeed, we found that the total phenols concentration of wheat plants grown under different $\mathrm{P}$ treatments was negatively correlated with the $\mathrm{P}$ concentration in both shoots $(r=-0.252$, $P \leq 0.01)$ and roots $(r=-0.499, P \leq 0.01)$ (Table 1$)$.

Regression analysis indicates the same pattern of accumulation of total phenols in roots of P-efficient $v s$ P-inefficient genotypes (the same slopes, different intercept,
Figure 5B and Table 3). The model shows that roots of P-inefficient genotypes constitutively accumulate on average about $137 \mu \mathrm{g} \mathrm{CAE} \mathrm{g}^{-1}$ more than P-efficient genotypes along the experimental gradient of P supply (regression coefficient for P efficiency, Table 3). On the other hand, the confocal microscopy analysis showed differential changes in the pattern of root lignin accumulation as a consequence of P supply. As shown in Figure 6, lignin accumulation tended to increase as a consequence of $\mathrm{P}$ shortage. Thus, safranine staining displayed an evident enhancement of the lignin accumulation in the roots of the most studied wheat cultivars (i.e. Púrpura, BTP-314, Don Crac, Innovo, Bakán, Dollinco, Impulso and Ilustre) subjected to P deficiency compared to the control. However, the deposition of lignin remained unchanged with respect to $\mathrm{P}$ treatments in cvs. Maxi and Fritz. 


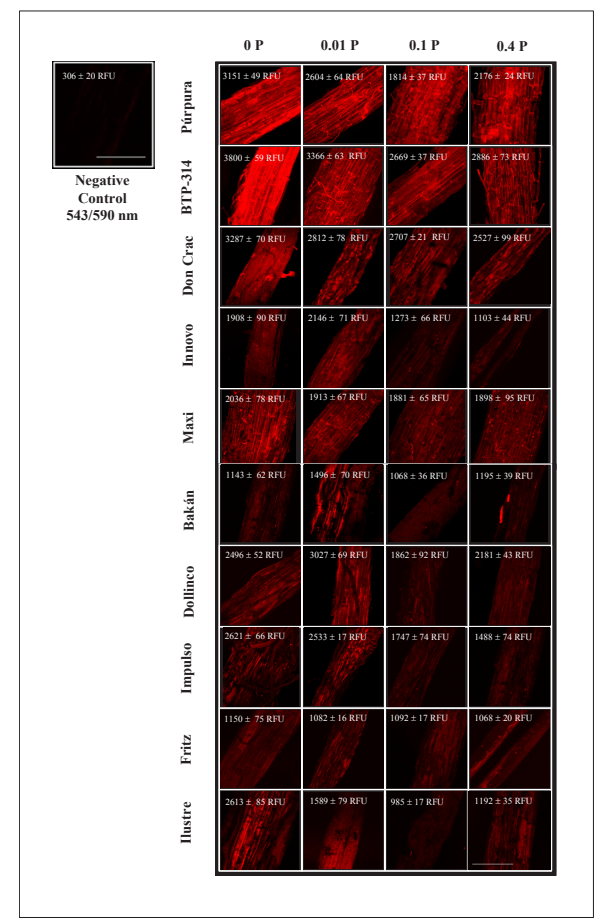

Figure 6. Representative confocal images of lignin accumulation pattern in roots of wheat cultivars subjected to different $P$ treatments. Lignin fluorescence was collected by excitation/emission wave lengths $543 \mathrm{~nm} / 590 \mathrm{~nm}$ by Confocal Laser Scanning Microscope. Bar in the control image represent $300 \mu \mathrm{m}$.

\section{Discussion}

Several studies have indicated that $\mathrm{P}$ deficiency is one of the major limiting factors for crop production in many parts of the world. Considerable research efforts has so far been devoted to analyze the constraint of $\mathrm{P}$ deficiency on plants, but because different species and genotypes can vary greatly in their adaptive mechanisms to $\mathrm{P}$ stress there is no universal mechanism that explains the nature of plant P-tolerance (Gunes et al., 2006). Current evidence has shown that secondary metabolites such as phenolic compounds play a significant role in ameliorating P deficiency in plants (Plaxton and Carswell 1999; Dakora and Phillips 2002; Vance et al., 2003; Malusà et al., 2006;
Hernández and Munné-Bosch 2015). Nevertheless, to our knowledge the role of phenols production with either antioxidant or structural function induced by $\mathrm{P}$ deficiency are poorly understood as yet.

In present study, wheat cultivars displayed differential responses to $\mathrm{P}$ deficiency conditions in terms of $\mathrm{P}$ concentration, plant growth, oxidative damage and phenols accumulation (see Figures 1-6). Phosphorus concentration was steadily increased in all wheat cultivars as the level of applied $\mathrm{P}$ raised from 0 to 0.4 mM P (Figure 1). The clear distinction between the genotypes of contrasting P efficiency was also observed (Table 2, Figure 2). However, P efficiency could only partly be assessed by this experimental design; P mobilization from sparingly soluble P frac- 
tions in soil, which is a key mechanism of efficient $\mathrm{P}$ acquisition, could not be evaluated in hydroponic experiments. It can be assumed that the differences between $\mathrm{P}$ efficient and $\mathrm{P}$ inefficient genotypes would be more pronounced in soil experiments. As expected, addition of both $0.1 \mathrm{mM} \mathrm{P}$ and $0.4 \mathrm{mM}$ P provided sufficient $\mathrm{P}$ levels according to the nutritional requirements of wheat (Jones et al., 1991). However, the shoot $\mathrm{P}$ concentration in all the studied cultivars either grown without $\mathrm{P}$ or supplied with $0.01 \mathrm{mM}$ P showed a P deficient level (Figure 1A; Bergmann, 1992). Lower P accumulation was observed in cvs. BTP-314 and Púrpura when grown either without $\mathrm{P}$ or with 0.01 $\mathrm{mM} P$ compared with those supplied with an adequate P dose, whereas cvs. Ilustre, Impulso and Fritz exhibited a higher $\mathrm{P}$ concentration under $\mathrm{P}$ shortage.

It is well documented in the literature that $P$ deficiency affects plant growth and metabolism in several plant species (Vance et al., 2003; Shen et al., 2011; Balemi and Negisho 2012). According to our results, significant differences in the pattern of plant growth were found depending on the treatment and cultivar (Figures $1 \mathrm{C}$-D). Since P deficiency alters the photosynthesis, synthesis of carbohydrates, cell division and cell elongation (Vance et al., 2003; Shen et al., 2011; Hernández and Munné-Bosch 2015), the decrease in $\mathrm{P}$ uptake by plants subjected to P-deprivation further decreased shoot DW in almost all the examined cultivars (Figure 1C).

On the other hand, with exception of cv. Innovo, we found an increment of root biomass when wheat cultivars were treated with low P doses (Figure 1D), leading to a greater root/ shoot ratio (Figure 1E). These findings were supported by the positive correlation found between $\mathrm{P}$ concentration and shoot DW, but a negative relationship between $\mathrm{P}$ concentration and root biomass (Table 1). Higher root/shoot DW ratio is a common plant response to limited P supply (Vance et al., 2003; Balemi and Negisho 2012; Niu et al.,
2012). Reduced shoot growth under $P$ stress leads to diminished shoot demand of assimilates generating a preferential distribution of carbohydrates toward the roots (Vance et al., 2003; Balemi and Negisho 2012; Kostic et al., 2015). Consequently, increased delivery of sugars to plant roots can trigger changes in gene expression as well as alter the biochemistry or architecture of roots as reported by Hammond and White (2011). These adaptive responses of plants to P deficiency can generate an increased root growth, thus improving the plant ability to take up more $\mathrm{P}$ when this nutrient is scarce (Niu et al., 2012).

The effect of $\mathrm{P}$ deficiency also depends on the capacity of plants to adapt to the oxidative stress induced by $\mathrm{P}$ limitation. Briefly, the balance of reactive oxygen species (ROS) production can be altered under P stress, affecting the normal cellular metabolism through the peroxidation of the membrane lipids, oxidation of the proteins or damage of nucleic acids and other cellular components (Juszczuk et al., 2001). In our study, the amount of TBARS was examined as an index of oxidative stress (Figures 3A-B). In agreement with previous reports (Juszczuk et al., 2001; Chen et al., 2015), we found a significant increase of the lipid peroxidation in the most wheat cultivars grown under Pdeficient condition (Figures 3A-B). Cultivars Innovo, Púrpura, Dollinco, Don Crac and BTP-314 produced a higher amount of shoot TBARS under P deficiency than the other cultivars (Figure 3A), whereas the roots of cvs. Fritz and Dollinco did not show any differences in the lipid peroxidation among $\mathrm{P}$ treatments (Figure 3B). Interestingly, we also found significant negative relationships between lipid peroxidation and either shoot $\mathrm{P}$ concentration $(r=-0.720, P \leq 0.01)$ or shoot dry biomass $(r=-0.325, P \leq 0.01)$ of wheat cultivars grown under different $P$ levels (Table 1). The greater shoot TBARS observed under $\mathrm{P}$ deprivation (Figure 3A) coincided with an apparent increase of chloroplasts $\mathrm{H}_{2} \mathrm{O}_{2}$ production in all wheat cultivars 
subjected to low P supply (Figure 4), which is in agreement with the previous reports of Juszczuk et al. (2001) and Malusà et al. (2002). Hydrogen peroxide is one of the most abundant ROS in plants. Depending on the equilibrium between generation of $\mathrm{H}_{2} \mathrm{O}_{2}$ and its scavengers, it may cause oxidative damage or functions as a cellular signaling molecule regulating hormone signaling and several plant stress responses (Juszczuk et al., 2001). Accordingly, P deficiency retards the rate of electron transfer in the electron transport systems leading to both the over-accumulation of $\mathrm{H}_{2} \mathrm{O}_{2}$ and the redox changes that induce oxidative damage (Juszczuk et al., 2001).

Plants have developed an efficient enzymatic and non-enzymatic antioxidant system to counteract the ROS-induced tissue injury. Among non-enzymatic antioxidant, phenolic compounds form a major group of plant secondary metabolites that may act as ROS scavengers improving the tolerance to oxidative damage (Plaxton and Carswell 1999; Vance et al., 2003; Hernández and Munné-Bosch, 2015). It is widely accepted that P deficiency also may lead to the accumulation of phenolic compounds, such as flavonoids (Plaxton and Carswell 1999) and anthocyanins (Vance et al., 2003; Hernández and Munné-Bosch, 2015). In the present study, we found that almost all examined wheat cultivars increased their phenols concentration when no P or $0.01 \mathrm{mM}$ P was applied (Figures 3C-D), as a consequence of increased oxidative damage triggered by $\mathrm{P}$ deficiency (Figures 3A-B). Cv. Púrpura, which exhibited the largest oxidative damage (Figure $3 \mathrm{~A}$ ) and considerable reduction of shoot growth (Figure 1C) under P limitation, also showed a significant enhancement of phenols concentration (Figure 3C) likely as a strategy aimed to counteract oxidative stress. Moreover, genotypes with contrasting P efficiency (Figure 2) expressed different patterns of phenols accumulation in both shoots and roots (Figure 5,
Table 3). In this sense, Juszczuk et al. (2004) reported an elevated concentration of anthocyanins and total phenols in P-deficient leaves of bean plants. Likewise, Chen et al. (2013) suggested that P nutrition may control the synthesis of anthocyanins in the flower stalk by regulating the activities of the phenylalanine ammonialyase (PAL) and chalcone isomerase (CHI). Moreover, there is increasing evidence indicating that phenolic compounds are involved in the development of resistance in plants (Shalaby and Horwitz 2015).

Induction of structural phenols like lignin is another frequent response of plants subjected to various abiotic stresses (Frei, 2013). Similar to Eppendorfer and Eggum (1994), we detected an apparent increase of root lignin accumulation under $\mathrm{P}$ limitation (Figure 6). In fact, stronger staining intensity was observed in the roots of cvs. BTP-314, Púrpura, Ilustre, Don Crac, Dollinco and Innovo grown either without or with $0.01 \mathrm{mM} P$ supply indicating that a considerable increase of structural phenols in roots was generated by P-deficiency stress (Figure 6). Despite the information about the influence of $\mathrm{P}$ supply on lignin biosynthesis is scarce, the stress-induced lignin accumulation has been reported under other mineral imbalances including toxicities of $\mathrm{Al}$ or boron (B) (Cervilla et al., 2009; Ma et al., 2012). Mineral toxicities can induce root lignification as a consequence of increased $\mathrm{H}_{2} \mathrm{O}_{2}$ levels and the activation of enzymes involved to the lignin biosynthesis (for review, see Frei, 2013), In addition, it has been reported that nitrogen $(\mathrm{N}), \mathrm{Ca}$ and manganese $(\mathrm{Mn})$ deficiencies (for review, see Frei, 2013) also can affect the plant lignin levels. In turn, enhanced lignin content it has been observed in plants grown under salinity, drought, or UV radiation (for review, see Frei, 2013). Thus, further studies are needed to advance in the understanding of the implication of lignin accumulation under $P$ stress. 
Furthermore, based in our results about $\mathrm{P}$ uptake, plant growth, lipid peroxidation and phenols accumulation (see Figures 1-6), wheat cultivars can be ranked according to their susceptibly to $\mathrm{P}$ deficiency in the following decreasing order: Púrpura $\approx$ BTP-314 $>$ Don Crac $>$ Innovo $>$ Maxi $\approx$ Bakán $>$ Dollinco $>$ Impulso $>$ Fritz $>$ Ilustre.

\section{Conclusions}

Overall, almost all examined wheat cultivars increased both the oxidative damage and the root lignification under P deficiency, whereas a differential production of antioxidant phenols could be considered as a strategy of wheat genotypes aimed to cope with P stress. Moreover, our evidence indicates that $\mathrm{P}$ efficiency of a cultivar modulates the accumulation of total phenols since more phenols were accumulated in tissues of Pinefficient genotypes than P-efficient genotypes under $\mathrm{P}$ deficiency. In fact, a clear relationship between $\mathrm{P}$ efficiency and phenol metabolism was found. These outcomes can be useful as a base of further researches related with improvement of grain quality and yield of wheat plants grown on $\mathrm{P}$ deficient soils.

\section{Acknowledgments}

This work was supported by the FONDECYT project 1161326. The authors are grateful to Semillas Baer and the Instituto de Investigaciones Agropecuarias (INIA) for contribute with the seeds of different wheat cultivars used in this work. In addition, we thank the Scientific and Technological Bioresource Nucleus of Universidad de La Frontera (BIOREN-UFRO) for providing access to specialized equipment for use in flow cytometry and laser scanning confocal microscopy analysis. We also acknowledge to Dirección de Investigación of Universidad de La Frontera, and MN and NN thank the Serbian Ministry of Education, Science and Technological Development (OI-173028).

\section{References}

Balemi, T., Negisho, K. 2012. Management of soil phosphorus and plant adaptation mechanisms to phosphorus stress for sustainable crop production: a review. J. Soil Sci. Plant Nutr. 12: 547-562.

Bergmann, W. 1992. Nutritional disorders of plants. Development, visual and analytical diagnosis. Stuttgart: Gustav Fischer Verlag 741p.

Bhuiyan, N.H., Selvaraj, G., Wei, Y., King, J. 2008. Gene expression profiling and silencing reveal that monolignol biosynthesis plays a critical role in penetration defense in wheat against powdery mildew invasion. J. Exp. Bot. 60: 509-521.

Cervilla, L.M., Rosales, M.A., Rubio-Wilhelmi, M.M., Sánchez-Rodríguez, E., Blasco, B., Ríos, J.J., Romero, L., Ruiz, J.M. 2009. Involvement of lignification and membrane permeability in the tomato root response to boron toxicity. Plant Sci. 176: 545-552.

Chen, R., Song, S., Li, X., Liu, H., Huang, D. 2013. Phosphorus deficiency restricts plant growth but induces pigment formation in the flower stalk of Chinese kale. Hortic. Environ. Biotechnol. 54: 243-248.

Chen, S., Zhao, H., Ding, G., Xu, F. 2015. Genotypic differences in antioxidant response to phosphorus deficiency in Brassica napus. Plant Soil 391: 19-32.

Dakora, F.D., Phillips, D.A., 2002. Root exudates as mediators of mineral acquisition in low-nutrient environments. Plant Soil 245: 35-47.

Dixon, R. A., Achnine, L., Kota, P., Liu, C. J., Reddy, M. S., Wang, L. 2002. The phenylpropanoid pathway and plant defense - a genomics perspective. Molecular Plant Pathology, 3: 371-390. 
Du, Z., Bramlage, W.J. 1992. Modified thiobarbaturic acid assay for measuring lipid peroxidation in sugar rich plant tissue extracts. J. Agric. Food Chem. 40: 1566-1570.

Eppendorfer, W.H., Eggum, B.O. 1994. Effects of sulphur, nitrogen, phosphorus, potassium, and water stress on dietary fibre fractions, starch, amino acids and on the biological value of potato protein. Plant Food Hum. Nutr. (Formerly Qualitas Plantarum) 45: 299-313.

Frei, M. 2013. Lignin: characterization of a multifaceted crop component. Sci. World J. 2013.

Gourley, C.J.P., Allan, D.L., Ruselle, M.P. 1993, Defining phosphorus efficiency in plants. Plant Soil 155: 289-292.

Gunes, A., Inal, A., Alpaslan, M., Cakmak, I. 2006. Genotypic variation in phosphorus efficiency between wheat cultivars grown under greenhouse and field conditions. Soil Sci. Plant Nutr. 52: 470478.

Hammond, J.P., White, P.J. 2011. Sugar signaling in root responses to low phosphorus availability. Plant Physiol. 156: 1033-1040.

Hernández, I., Munné-Bosch, S. 2015. Linking phosphorus availability with photo-oxidative stress in plants. J. Exp. Bot. 66: 2889-2900.

Hinsinger, P. 2001. Bioavailability of soil inorganic $\mathrm{P}$ in the rhizosphere as affected by root-induced chemical changes: a review. Plant Soil. 237: 173195.

Jones, J.B. Jr., Wolf, B., Mills, H.A. 1991. Plant Analysis Handbook: A Practical. Sampling, Preparation, Analysis, and Interpretation Guide. MicroMacro Publishing, Athens, Georgia).

Juszczuk, I., Malusà, E., Rychter, A.M. 2001. Oxidative stress during phosphate deficiency in roots of bean plants (Phaseolus vulgaris L.). J. Plant Physiol. 158: 1299-1305.
Juszczuk, I.M., Wiktorowska, A., Malusá, E., Rychter, A.M. 2004. Changes in the concentration of phenolic compounds and exudation induced by phosphate deficiency in bean plants (Phaseolus vulgaris L.). Plant Soil 267: 41-49.

Kochian, L.V., Hoekenga, O.A., Pineros, M.A. 2004. How do crop plants tolerate acid soils? Mechanisms of aluminium tolerance and phosphorus efficiency. Annu. Rev. Plant Biol. 55: 459-493.

Kostic, L., Nikolic, N., Samardzic, J., Milisavljevic, M., Maksimovic, V., Cakmak, D., Manojlovic, D., Nikolic, M. 2015. Liming of anthropogenically acidified soil promotes phosphorus acquisition in the rhizosphere of wheat. Biol. Fertil. Soils 51: 289-298.

Ma, B., Gao, L., Zhang, H., Cui, J., Shen, Z. 2012. Aluminum-induced oxidative stress and changes in antioxidant defenses in the roots of rice varieties differing in Al tolerance. Plant Cell Rep. 31: 687-696.

Malusà, E., Laurenti, E., Juszczuk, I., Ferrari, R.P., Rychter, A.M. 2002. Free radical production in roots of Phaseolus vulgaris subjected to phosphate deficiency stress. Plant Physiol. Biochem. 40: 963-967.

Malusà, E., Russo, M.A., Mozzetti, C., Belligno, A. 2006. Modification of secondary metabolism and flavonoid biosynthesis under phosphate deficiency in bean roots. J. Plant Nutr. 29: 245-258.

Maxwell, D.P., Wang, Y., McIntosh, L. 1999. The alternative oxidase lowers mitochondrial reactive oxygen production in plant cultures. Proc. Natl. Acad. Sci. U. S. A. 96: 8271-8276.

Neumann, G., Römheld, V. 2001. The release of root exudates as affected by the plant's physiological status, in: Pinton, R., Varanini, Z., Nannipieri, P. (Eds.), The rhizosphere: biochemistry and organic substances at the soil-plant interface, Marcel Dekker Publishing, New York, USA, pp. 41-93. 
Niu, Y.F., Chai, R.S., Jin, G.L., Wang, H., Tang, C.X., Zhang, Y.S. 2012. Responses of root architecture development to low phosphorus availability: a review. Ann. Bot. 112: 391-408.

ODEPA. 2016. Oficina de Estudios y Políticas Agrarias. ODEPA, Santiago, Chile. Available online at: http://www.odepa.cl/rubro/cereales/ (Accessed March 2017).

Plaxton, W.C., Carswell, M.C. 1999. Metabolic aspects of the phosphate starvation responses in plants, in: Lerner, H.R. (Ed), Plant responses to enviromental stress: from phytohormones to genome reorganization, Marcel Dekker Publishing: New York, USA, pp. 350-372.

Redel, Y., Cartes, P., Demanet, R., Velásquez, G., Poblete-Grant, P., Bol, R., Mora, M. L. 2016. Assessment of phosphorus status influenced by $\mathrm{Al}$ and Fe compounds in volcanic grassland soils. J. Soil Sci. Plant Nutr. 16: 490-506.

Sadzawka, A., Carrasco, M.A., Demanet, R., Flores, H., Grez, R., Mora, M.L., Neaman, A. 2007. Métodos de Análisis de Tejidos Vegetales. Segunda Edición. Serie Actas INIA No 40. Santiago, Chile.

SAG. 2017. Variedades de trigo harinero bajo certificación 2016-2017. Servicio Agrícola y Ganadero. SAG, Santiago, Chile. Available online at: http:// www.sag.cl/ambitos-de-accion/certificacionde-semillas-y-plantas/149/publicaciones?field tema_otros_documentos_tid=All\&field tipo_de publicacion tid=All\&field fecha otros value $\% 5$ Bvalue $\% 5 \mathrm{D} \% 5$ Byear $\% 5 \mathrm{D}=\&$ title $=$ Variedades $+\mathrm{d}$ e+trigo+harinero+bajo+certificaci\%C3\%B3n\&it ems per page $=15$.
Sant'Anna, C., Costa, L.T., Abud, Y., Biancatto, L., Miguens, F.C., Souza, W. 2013. Sugarcane cell wall structure and lignin distribution investigated by confocal and electron microscopy. Microsc. Res. Tech.76: 829-834.

Shalaby, S., Horwitz, B.A. 2015. Plant phenolic compounds and oxidative stress: integrated signals in fungal-plant interactions. Curr. Genet. 61: 347-357.

Shen, J., Yuan, L., Zhang, J., Li, H., Bai, Z., Chen, X., Zhang, W., Zhang, F. 2011. Phosphorus dynamics: from soil to plant. Plant physiol. 156, 997-1005.

Slinkard, K., Singleton, V.A. 1977. Total phenol analysis: automation and comparison with manual methods. Am. J. Enol. Vitic. 28: 29-55.

Taylor, G.J., Foy, C.D. 1985. Mechanisms of aluminum tolerance in Triticum aestivum L. (wheat). II. Differential pH Induced by Spring Cultivars in Nutrient Solutions. Am. J. Bot. 72: 695-701.

Tsai, S.M., Phillips, D.A. 1991. Flavonoids released naturally from alfalfa promote development of symbiotic Glomus spores in vitro. Appl. Environ. Microbiol. 57: 1485-1488.

Vance, C.P., Uhde-Stone, C., Allan, D.L. 2003. Phosphorus acquisition and use: critical adaptations by plants for securing a nonrenewable resource. New Phytol. 157: 423-447.

Velásquez, G., Calabi-Floody, M., Poblete-Grant, P., Rumpel, C., Demanet, R., Condron, L., Mora, M. L. 2016. Fertilizer effects on phosphorus fractions and organic matter in Andisols. J. Soil Sci. Plant Nutr. 16: 294-309. 